Strategi Membangun Jaringan... Oleh: Khairan

\title{
STRATEGI MEMBANGUN JARINGAN KERJASAMA BISNIS BERBASIS SYARIAH
}

\author{
Oleh: \\ Khairan \\ emhakhairan@gmail.com \\ Institut Agama Islam Tribakti (IAIT) Kediri
}

\section{Abstrak}

Strategi adalah penerapan sasaran dalam jangka panjang sebuah perusahaan, dan arah tindakan serta alokasi sumber daya yang diperlukan untuk mencapai sasaran dan tujuan. Strategi sering digunakan oleh perusahaan-perusahaan dalam mencapai tujuannya, begitu juga dalam dunia bisnis. Kerja sama dalam usaha bisnis atau perdagangan bersama dalam dunia modern disebut dengan joint venture. Secara bahasa, kerja sama (al-syirkah) adalah campuran antara sesuatu dengan yang lain sehingga sulit dibedakan. Al-syirkah atau musyarakah adalah akad kerja sama antara dua pihak atau lebih untuk usaha tertentu yang masing-masing pihak memberikan kontribusi dana dengan kesepakatan bahwa keuntungan dan resiko akan ditanggung bersama sesuai dengan kesepakatan. Syariat Islam memperbolehkan persekutuan, korporasi atau berkerja sama bisnis, yang bersih dari riba, Islam sangat menganjurkan kerja sama dalam hal pembiayaan dari sebagian modal usaha, yang juga melibatkan bank dalam proses manajemennya. Adapun pembagian keuntungan dan kerugian dalam pembiayaan musyarakah tersebut sesuai dengan perjanjian yang disepakati bersama. Salah satu pihak mendapatkan setengah, sepertiga, seperempat atau kurang dari itu. Sedangkan sisanya untuk yang lainnya. Jadi setiap pihak, akan mendapatkan bagian apabila usahanya untung, dan sama-sama menanggung kerugian apabila usahanya mengalami kerugian.

Kata Kunci : Strategi Membangun Jaringan, Kerjasama, Bisnis Syariah. 


\section{Pendahuluan}

Sebuah perusahaan atau lembaga bisnis dalam menghadapi persaingan bisnis sebaiknya mempunyai strategistrategi yang diterapkan agar perusahaan atau lembaga bisnis tersebut dapat bertahan dan mampu bersaing dengan para pesaing bisnisnya. Selain itu dengan menetapkan dan menerapkan sebuah strategi perusahaan juga harus memperhatikan beberapa faktor agar bisa menetapkan kebijakan perusahaan dengan benar, untuk melaksanakan jaringan kerjasama dalam bisnisnya.

Begitu juga dalam kehidupannya sehari-hari manusia tidak dapat mampu memenuhi seluruh kebutuhan hidupnya tanpa bantuan orang lain. Demikian juga dalam konteks bisnis, seberapapun hebatnya kemampuan seseorang tidak mungkin bisa mengembangkan bisnisnya tanpa bantuan dan keterlibatan orang lain dalam perjalanan usahanya, misalnya saja karyawan, konsumen, pemasok, perbankan dan pemerintah (dalam bentuk aturan). Menjadi pedagang retail misalnya dia tidak cukup hanya punya toko yang besar tanpa barang hasil produksi orang lain. Begitu juga pengusaha yang mempunyai perusahaan memerlukan distribusi untuk menyalurkan produknya agar sampai kepada konsumen. Saling membutuhkan dalam memenuhi inilah menjadi dasar terbentuknya kerja sama antar perusahaan ataupun kerja sama antara invidu dengan individu lainnya. ${ }^{1}$

Sebelum perusahaan berjalan atau sedang merumuskan kembali arah bagi perusahaannya maka perusahaan perlu menerapkan tujuan dari filosofi dasar yang akan menentukan bentuk sosok strateginya, tujuan mendasar yang membedakan suatu perusahaan dengan perusahaan lain yang sejenis dan yang menjelaskan cakupan operasinya dalam bentuk produk dan pasar. Misi perusahaan juga diartikan sebagai pernyataaan atau rumusan umum yang luas dan bersifat tahan lama tentang keinginan atau maksud perusahaan.

${ }^{1}$ Ali Hasan, Manajemen Bisnis Syariah (Yogyakarta: Pustaka Pelajar, 2009), h. 240. 
Begitu juga perusahaan perlu menetapkan tujuan agar memungkinkan untuk menentukan apa yang harus dilakukan dalam mengembangkan rencana-rencana yang efektif, dalam menentukan sasaran dan menilai hasilnya. Untuk merumuskan tujuan perusahaan, perlu diperhatikan keseimbangan dengan memadukan berbagai kepentingan berbagai sumber atau pihak yang terlibat dalam kerja sama. ${ }^{2}$

Untuk melaksanakan tujuan strategis, menjelaskan kerangka kerja misi strategis perusahaan atau lembaga bisnis yang merupakan pernyataan dari tujuan perusahaan dan ruang lingkup operasinya dalam hal produk dan pasar. Sebuah misi efektif dirumuskan ketika perusahaan atau lembaga bisnis memiliki kesadaran yang sangat kuat akan apa yang ingin dilakukannya dengan standar-standar etika yang akan mengatur perilaku dalam mencapai tujuan tersebut. ${ }^{3}$

Menurut ekonomi perusahaan kerja sama seperti ini dikenal dengan modal venture atau joint venture, di mana suatu perusahaan melakukan penggabungan antara dua pihak atau lebih yang mengumpulkan modal untuk mendirikan badan usaha dengan perjanjian tertentu, ${ }^{4}$ Pelaksanaan yang dilakukan suatu perusahaan atau lembaga bisnis yang melakukan pembiayaan dalam bentuk penyertaan modal ke dalam suatu perusahaan yang menerima bantuan pembiayaan dengan cara melakukan penyertaan ikut secara langsung ke dalam perusahaan yang dibiayai. Kegiatan yang dilakukan antara lain, bersifat jangka panjang, keuntungan yang dipilih bersifat capital gain, deviden atau tergantung penyertaan modal di bidang jenis yang dikerjasamakan, berbentuk usaha baru atau pengembang suatu usaha baru.

Dalam bermuamalah sangat tegas Allah Swt, dengan firmannya, tolong-menolonglah kalian semua dalam mengerjakan kebajikan dan takwa, dan jangan tolong menolong dalam berbuat dosa dan pelanggaran, dan bertakwalah kamu kepada Allah sesungguhnya Allah sangat berat siksaan-Nya

\footnotetext{
${ }^{2}$ Priyono, Pengantar Manajemen (Sidoarjo: Zitama,2014), h. 51.

${ }^{3}$ Michael A. Hitt dkk, Manajemen Strategis (Jakarta: Salemba Empat 2001), h. 135 .

${ }^{4}$ Buchari Alma, Pengantar Bisnis (Bandung: Alfabeta, 2010), h. 45.

Volume 29 Nomor 2 Juli-Desember 2018 
(QS, al-Maidah: 5). Hal ini yang menjadi prinsip manusia sebagai makhluk sosial yang memperbolehkan kerja sama baik secara perusahaan maupun antara individu dengan individu lainya, dalam hal tolong-menolong mengerjakan kebaikan dengan kebajikan, dan kompetisi untuk mengerjar ketakwaan. Sebaliknya dilarang berkerja sama dalam untuk mencelakakan orang lain, melakukan penipuan kepada orang lain baik sendirisendiri maupun berjamaah, berbuat dosa, batil dan zalim.

Islam juga sangat menganjurkan setiap umatnya untuk mencari dan memdapatkan rezeki, Islam sangat menekankan, mewajibkan aspek kehalalan, baik dari segi perolehan maupun pendayagunaannya, pengolahannya dan pembelanjaannya. Bisnis Syariah dapat diartikan sebagai serangkaian aktivitas bisnis dalam berbagai bentuknya yang tidak dibatasi, namun dibatasi dalam cara perolehan dan pendayagunaan hartanya ada atuaran halal dan haram. Dengan kata lain, pelaksanaan bisnis harus tetap berpegang pada ketentuan syariat, aturan-aturan dalam al-Qur'an dan al-Hadits. Syari at merupakan nilai utama yang menjadi payung strategis maupun taktis bagi pelaku kegiatan ekonomi bisnis. ${ }^{5}$

Syariat Islam memperbolehkan bersekutu korporasi atau berkerja sama bisnis, yang bersih dari riba, Islam sangat menganjurkan kerja sama dalam hal pembiayaan dari sebagian modal usaha, yang juga melibatkan bank dalam proses manajemennya. Adapun pembagian keuntungan dan kerugian dalam pembiayaan musyarakah tersebut sesuai dengan perjanjian yang disepakati bersama. Salah satu pihak mendapatkan setengah, sepertiga, seperempat atau kurang dari itu. Sedangkan sisanya untuk yang lainnya. Jadi masing-masing pihak, akan mendapatkan bagian apabila usahanya untung, dan sama-sama menanggung kerugian apabila usahanya mengalami kerugian. Oleh karena itu kejujuran dalam mengelola dan keadilan berbagi hasil ataupun upah menjadi syarat dalam kerja sama bisnis berbasis syariah.

5 Rivai, Veithzal, dkk.. Islamic Business and Economic Ethics (Jakarta: Bumi Aksara, 2012), h. 


\section{Pembahasan}

\section{Konsep Strategi Bisnis}

Strategi sering digunakan oleh perusahaan-perusahaan dalam mencapai tujuannya, begitu juga dalam dunia bisnis. Biasanya istilah strategi digunakan dalam perang guna memenangkan pertempuran dengan lawannya, namun kali ini strategi juga dipergunakan oleh perusahaan dalam memasarkan produknya. Adapun pengertian strategi ada beberapa tokoh yang mengemukakan pendapat di antaranya adalah Alfred Chandler mengemukakan strategi adalah penerapan sasaran dalam jangka panjang sebuah perusahaan, dan arah tindakan serta alokasi sumber daya yang diperlukan untuk mencapai sasaran dan tujuan tersebut ${ }^{6}$.

Begitu pula seperti disampaikan oleh Buzzel dan Gale sebagaimana dikutip oleh Panji Anoraga mendefinisikan strategi adalah kebijakan dan keputusan kunci yang digunakan oleh manajemen, yang memiliki dampak besar pada kinerja keuangan. Kebijakan dan keputusan ini biasanya melibatkan sumber daya yang penting dan tidak dapat diganti dengan mudah. $^{7}$

Demikian juga trategi menurut Kenneth Andrew yang dikutip oleh Panji Anoraga adalah pola sasaran, maksud atau tujuan dan kebijakan, serta rencana-rencana penting untuk mencapai tujuan itu, yang dinyatakan dengan cara seperti menetapkan bisnis yang dianut oleh perusahaan, dan jenis atau akan menjadi jenis apa perusahaan ini. ${ }^{8}$ Basu Swasta dan Irawan menyatakan bahwa strategi adalah suatu rencana yang diutamakan untuk mencapai tujuan tersebut (perusahaan). ${ }^{9}$

Dari definisi di atas jelaslah sebuah perusahaan dalam menjalankan roda bisnisnya harus memiliki strategi yang harus dilakukan oleh sebuah perusahaan agar bisa tercapai sebuah tujuan perusahaan dengan baik, karena apabila sebuah

\footnotetext{
${ }^{6}$ Ibid.

${ }^{7}$ Panji Anoraga, Manajemen Bisnis (Jakarta: Asdi Mahasatya, 2004), h. 339.

${ }^{8}$ Ibid.

9 Basu Swastha dan Irawan, Manajemen Pemasaran Modern (Yogyakarta: Liberty, 2005), h. 4.

Volume 29 Nomor 2 Juli-Desember 2018 
perusahaan tidak memiliki strategi maka akan berakibat di setiap unit organisasinya akan kehilangan arah dan tujuan, bahkan sangat sulit bagi sebuah perusahaan atau lembaga bisnis kalau ingin berkerja sama dengan perusahaan lain.

\section{Langkah-langkah dalam Perumusan Strategi Bisnis}

Beberapa langkah yang perlu dilakukan perusahaan dalam merumuskan strategi, yaitu:

a. Mengidentifikasi lingkungan yang akan dimasuki oleh perusahaan di masa depan dan menentukan misi perusahaan untuk mencapai visi yang dicita-citakan dalam lingkungan tersebut.

b. Melakukan analisis lingkungan internal dan eksternal untuk mengukur kekuatan dan kelemahan serta peluang dan ancaman yang akan dihadapi oleh perusahaan dalam menjalankan misinya.

c. Merumuskan faktor-faktor ukuran keberhasilan (key success factors) dari strategi-strategi yang dirancang berdasarkan analisis sebelumnya.

d. Menentukan tujuan dan target terukur, mengevaluasi berbagai alternatif strategi dengan mempertimbangkan sumber daya yang dimiliki dan kondisi eksternal yang dihadapi.

e. Memilih strategi yang paling sesuai untuk mencapai tujuan jangka pendek dan jangka panjang. ${ }^{10}$

Dengan jaringan bisnis yang telah dibangun, peningkatan akselerasi daya saing tinggi, dengan adanya jaringan usaha dapat dilakukan: spesialisasi proses produksi berlangsung secara efisien, efisiennya biaya-biaya transaksi, fleksibilitas usaha dapat ditingkatkan karena adanya rekan bisnis yang terpercaya. $^{11}$

Salah satu strategi bisnis yang penting membangun jaringan kerja sama usaha bagi keberlangsungan daya saing bisnis, dapat mendorong setiap pebisnis berusaha keras untuk memeliharanya demi kepentingan jangka panjang dari bisnisnya.

${ }^{10}$ Ibid.

${ }^{11}$ Hasan, Manajemen Bisnis, h. 249. 
Pengikat kerja sama jaringan usaha pun tidaklah selalu berupa aturan, namun dapat juga berupa konvensi-konvensi informal. Proses pembentukan kerja sama jaringan usaha dapat dicapai melalui berbagai interaksi antar unit usaha yang pada akhirnya menentukan bentuk jaringan usaha yang disepakati. Dalam membangun kerja sama jaringan usaha umumnya didorong tiga faktor:

a. Pertukaran jaringan usaha ini terbentuk karena adanya relasi-relasi sosial antara para pelakunya, bisa perseorangan atau unit bisnis. Interaksi yang terjadi dimaksudkan untuk melakukan sejumlah pertukaran, baik secara langsung maupun tidak langsung, terhadap sesuatu yang dianggap berharga, seperti bahan baku, informasi, dan lain-lain.

b. Sumber daya untuk mengamankan sumber daya penting maka perlu dibentuk kerjasama dengan pihak lain yang menguasai sumber daya. Melalui kerja sama dengan pihak-pihak lain pemenuhan sumber daya dapat lebih terjamin.

c. Efisiensi biaya merupakan mekanisme pasar yang mengatur pelaku ekonomi untuk menghasilkan barang dan jasa secara efisien. Agar mendapatkan produk yang dibutuhkan diperlakukan biaya-biaya yang lebih besar, maka langkah yang dilakukan adalah mendorong terbentuknya konglomerasi usaha atau kerja sama antar perusahaan untuk mencapai skala ekonomi. ${ }^{12}$

Sebuah kerja sama jaringan usaha adalah jenis jaringan sosial yang ada dan menjadi alasan untuk kegiatan bisnis. Ada beberapa organisasi jaringan bisnis terkemuka yang menciptakan model aktivitas jaringan yang jika diikuti akan memungkinkan seorang pebisnis untuk membangun kerja sama bisnis baru dan menghasilkan peluang bisnis pada saat yang sama. Sebuah layanan jaringan profesional merupakan implementasi teknologi informasi untuk mendukung jejaring bisnis. Banyak pengusaha berpendapat jaringan bisnis adalah

12 Ibid., h. 250.

Volume 29 Nomor 2 Juli-Desember 2018 
metode yang lebih efektif dengan biaya rendah untuk menghasilkan bisnis baru dari pada iklan.

Hal ini karena jaringan bisnis adalah kegiatan murah yang melibatkan lebih banyak komitmen pribadi dari perusahaan. Bisnis jaringan dapat dilakukan dalam komunitas bisnis lokal, atau pada skala yang lebih besar melalui internet. Situs bisnis jaringan telah berkembang selama beberapa tahun terakhir karena kemampuan internet untuk menghubungkan orang dari seluruh dunia. Perusahaan-perusahaan internet sering membuat lead bisnis untuk dijual ke perusahaan besar dan perusahaan mencari sumber data.

Sumber atau acuan yang merupakan suatu pandanganpandangan yang mendasari tentang bisnis ini antara lain dikemukakan oleh Robert T. Kiyosaki dalam bukunya Rich Dad's The Business School For People Who Like Helping People, ia meruntuhkan prasangka banyak orang selama ini yang menganggap bisnis jaringan adalah bisnis bersistem piramida yang hanya menguntungkan orang yang berada di puncak bisnis tersebut. Sebaliknya, sistem/korporat tradisional yang selama ini kita kenal, justru adalah perusahaan dengan sistem piramida. ${ }^{13}$

Seperti kita ketahui bersama dalam bisnis tradisional, fokusnya adalah memiliki para karyawan (employee) dan orang yang bekerja sendiri (self-employee) untuk bekerja pada mereka. Dan sistem ini hanya mengijinkan satu orang saja mencapai puncak perusahaan. Sedangkan pada bisnis jaringan, yang menjadi salah satu kelebihannya adalah pemilik yang akan menciptakan aset. Yang merupakan para pemilik bisnis itu sendiri (business owner). Sedang yang lain bekerja di dalam sebuah kerja sama jaringan dan tugas mereka kemudian adalah menciptakan para business owner lainnya bekerja di bawah sebuah kerja sama jaringan bisnis. Karenanya Kiyosaki menganjurkan kepada semua karyawannya untuk mempertimbangkan pemasaran jaringan sebagai bisnis paruh

13 Ferry Roen, http://solusimlm.wordpress.com/2017/9./25/kenapabisnis-pemasaran-jaringan-lebih-unggul/ 
waktu mereka, sementara mereka juga bekerja pada bisnisnya secara purna waktu.

Dalam pandangannya, Kiyosaki mengingatkan untuk berhasil di bisnis pemasaran jaringan, sebaiknya motivasi utama bergabung dengan bisnis ini adalah untuk membantu diri sendiri sebagai alasan pertama dan membantu orang lain sebagai alasan kedua. Karena menurut Kiyosaki, kebanyakan orang bergabung hanya untuk mencari uang. Dan kalau mereka tidak mendapat uang dalam beberapa bulan atau tahun pertama, mereka menjadi patah semangat, berhenti dan sering kali menyebarkan kejelekan tentang industri pemasaran jaringan. Kiyosaki juga menambahkan, 'keunggulan bisnis ini tidak diukur dengan seberapa banyak uang anda peroleh, tetapi berapa banyak orang yang anda bantu dan berapa banyak hidup orang yang anda ubah. Karena memang ironinya, semakin banyak orang yang anda bantu mengubah hidupnya, anda semakin kaya.' ${ }^{14}$

Dan juga Ismail dan Karebet merekomendasikan model jaringan bisnis sebaiknya dibentuk secara vertikal, horizontal dan lateral sebagai berikut

a. Jaringan vertikal, merupakan jaringan yang terjadi antara usaha-usaha yang memiliki kaitan ke depan (hilir) atau ke belakang (hulu).

b. Jaringan horizontal, yakni hubungan antar usaha-usaha yang terkait langsung, namun tidak dalam sektor yang sama.

c. Jaringan lateral, adalah bentuk hubungan yang tidak terkait secara langsung, baik dari sektor yang sama maupun yang berbeda. ${ }^{15}$

Pendapat para ahli tentang teori yang sangat mendukung keunggulan bisnis jaringan ini adalah hukum Metcalf yang diciptakan oleh Robert Metcalf, pencipta ethernet (sebuah sistem dalam jaringan komputer). Hukum ini berbunyi: nilai ekonomis sebuah jaringan adalah jumlah pengguna. Dalam sebuah perumpamaan yang sederhana, jika di dunia ini terdapat hanya satu buah telepon maka tidak ada nilai ekonomis pada

14 Ibid.

${ }^{15}$ Hasan, Manajemen Bisnis, h. 251. 
telepon tersebut. Namun jika ada 2 telepon, menurut hukum Metcalf nilai ekonomisnya menjadi pangkat 2. Dan bila ada telepon ketiga, maka nilai ekonomis jaringan itu sekarang. Artinya, nilai ekonomis sebuah jaringan naik menurut deret ukur, bukan deret hitung. Dan inilah yang menjadi kekuatan dan nilai bisnis jaringan. ${ }^{16}$

Membangun usaha yang sukses membutuhkan banyak waktu dan motivasi untuk berkembang, sehingga untuk memiliki jaringan kerja sama dan rekan untuk memberikan energi yang positif yang membuat semakin giat dalam menjalankan usaha. Berikut adalah 5 keuntungan lain dalam membangun jaringan dan relasi dalam bisnis.

a. Dari mulut ke mulut. Jaringan bisnis yang baik akan membantu, tidak hanya dalam menambah relasi tetapi meningkatkan kualitas usaha. Dalam pelaksanaan trik marketing yang paling bagus adalah melalui pembicaraan mulut ke mulut. Dengan membangun jaringan dan menambah pergaulan, akan jauh lebih banyak orang yang akan tertarik dengan produk dan jasa yang ditawarkan. Seperti banyak yang diketahui, seorang individu gemar berbagi informasi kepada rekan dan sahabat mereka, termasuk membicarakan tentang usaha yang berkaitan.

b. Menambah koneksi dan relasi. Keuntungan terbesar dalam memiliki relasi yang luas adalah bertambahnya koneksi dalam menjalankan dunia usaha, orang akan menaruh kepercayaan lebih, dapat memberikan masukan kepada orang yang membutuhkan sesuatu dari bidangnya, dapat mendapatkan berbagai informasi yang berguna untuk kehidupan personal dan bisnis.

c. Memecahkan persoalan yang sama. Mencari orang yang menghadapi persoalan dalam dunia usaha yang hampir sama dengan apa yang sedang dialami. Cara mengatasi masalah tersebut dan mengambil contoh bagaimana mereka menyikapi masalah tersebut dan menerapkannya dalam usaha sendiri. Dalam arti lain, bertemu individu

${ }^{16}$ Ibid 
lain melalui koneksi bisnis yang akan berperan sebagai mentor, pada saat menghadapi persoalan. Dengan pertolongan seperti ini, jauh lebih percaya diri dalam mengambil keputusan.

d. Kesempatan yang tidak pernah terpikirkan sebelumnya. Dengan mengenal banyak pribadi lain, pikiran akan menjadi lebih terbuka dan mengetahui akan adanya kesempatan baru yang dapat diraih. Jika kita menutup diri untuk berkomunikasi dengan yang lain, maka kesempatan yang kita dapatkan akan menjadi sangat terbatas.

e. Bukan hanya untuk meningkatkan penjualan. Kebanyakan orang salah kaprah dalam mengartikan relasi bisnis karena semua dikaitkan dengan penjualan. Pada kenyataannya, membangun relasi bisnis tidak semata-mata demi meningkatkan penjualan. Dengan bekerjasama dengan orang lain, dapat meningkatkan pengetahuan yang dapat digunakan dalam mengembangkan usaha. ${ }^{17}$

\section{Konsep dasar Kerja sama dalam Bisnis Syariah.}

Konsep dasar kerja sama (al-syirkah) adalah pencampuran antara sesuatu dengan yang lain sulit dibedakan, sedangkan musyarakah secara etimologi berasal dari bahasa yang bermakna sekutu, menyetujui. Sedangkan menurut istilah musyarakah adalah akad kerja sama antara dua pihak atau lebih untuk suatu usaha tertentu di mana masing-masing pihak memberikan kontribusi dana (amal/expertise) dengan kesepakatan bahwa keuntungan dan resiko akan ditanggung bersama sesuai dengan kesepakatan. $^{18}$ Dari pengertian tersebut al-syirkah dapat dipahami bahwa ada beberapa unsur yang harus ada, seperti dua

\footnotetext{
${ }^{17} \mathrm{http}: / /$ blog.mokapos.com/2017/09/09/20.00.-keuntungan-dalammembangun-jaringan-dan-relasi-dalam-bisnis/

18 Muhammad Syafii Antonio, Bank Syariah dari Teori ke Praktek (Jakarta: Gema Insan, 2001), h. 97.
} 
orang yang berserikat(syarikayn), modal yang diserikatkan ( $r a s$ al-amal), pekerjaan ( amal) dan keuntungan (ribh). ${ }^{19}$

Kerja sama dalam usaha bisnis atau perdagangan bersama dalam dunia modern disebut dengan joint venture, secara bahasa lughatan kerja sama (al syirkah) adalah campuran antara sesuatu dengan yang lain sehingga sulit dibedakan. Adapun menurut istilah kerja sama (syirkah) merupakan keikutsertaan dua orang atau lebih dalam suatu usaha tertentu dengan sejumlah modal yang ditetapkan berdasarkan perjanjian untuk sama-sama menjalankan suatu usaha dan pembagian keuntungan atau kerugian dalam bagian yang ditentukan. Atau akad kerja sama antara dua pihak atau lebih untuk usaha tertentu yang masingmasing pihak memberikan kontribusi dana dengan kesepakatan bahwa keuntungan dan risiko akan ditanggung bersama sesuai dengan kesepakatan.

Senada dengan pendapat di atas Zuhaily dalam Ismail Nawawi menyebut syirkah ini dikenal juga dengan musyarakah adalah akad kerja sama antara dua pihak atau lebih untuk usaha tertentu yang masing-masing pihak memberikan kontribusi dana dengan kesepakatan bahwa keuntungan dan resiko akan ditanggung bersama sesuai dengan kesepakatan. ${ }^{20}$ Merupakan suatu akad kerja sama atau usaha dua atau lebih pemilik modal atau keahlian untuk melakukan jenis usaha yang halal dan produktif.

Dalam menjalankan roda bisnis, syariah melarang pemilik modal menentukan imbalan dalam batas tertentu atas uang yang diputar. Cara seperti ini tidak adil karena pemilik modal tidak ikut menanggung resiko tetapi ia hanya mendapatkan hasil. Cara semacam ini tidak dibenarkan karena di dalamnya termasud roh ribawi yang merusak keadilan dan semangat kerjasama. Padahal dalam dunia usaha ada kemungkinan tidak untung atau bahkan rugi oleh karena itulah dalam bisnis syariah investasi dikenal dengan istilah return on investmen losses, inilah yang membedakan dari bisnis yang berorientasi return on investmen

19 Khaerul Umam, Pasar Modal Syariah (Bandung: Pustaka Setia, 2013), h. 28.

${ }^{20}$ Ismail Nawawi, Fikih Muamalah Klasik dan Kontemporer (Bogor: Ghalia Indonesia, 2012), h. 151. 
profitable ala kapitalis dan sosialis. Apabila seseorang telah merelakan uangnya untuk syirkah (investasi untuk usaha bersama) dengan orang lain, maka dia harus berani menanggung segala resiko karena syirkah yang sudah disepakatinya, sesuai dengan kerja sama tersebut. ${ }^{21}$

Salah satu syarat kerja sama adalah kejujuran. Kejujuran tetap berlaku di negeri manapun dan kapanpun. Kejujuran akan mengikis kecurigaan dan persengketaan sehingga kerjasama dapat berjalan dalam jangka panjang dan saling menguntungkan. Sebagaimana Allah menjelaskan dalam kisah Nabi Daud (QS. Shaad (38): 24).

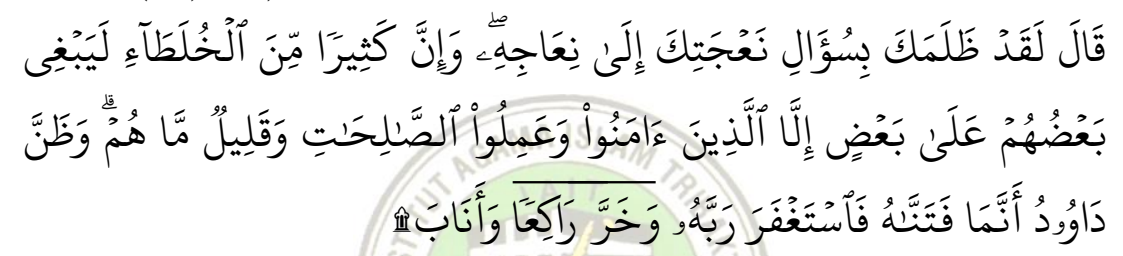

Terjemahnya: Daud berkata: "Sesungguhnya Dia telah berbuat zalim kepadamu dengan meminta kambingmu itu untuk ditambahkan kepada kambingnya, dan Sesungguhnya kebanyakan dari orang-orang yang berserikat itu sebahagian mereka berbuat zalim kepada sebahagian yang lain, kecuali orang-orang yang beriman dan mengerjakan amal yang saleh; dan Amat sedikitlah mereka ini". dan Daud mengetahui bahwa Kami mengujinya; Maka ia meminta ampun kepada Tuhannya lalu menyungkur sujud dan bertaubat. ${ }^{22}$

Hadits Nabi yang artinya: Dari Abu Hurairah, Sabda Rasulullah Saw Allah ta ala berfirman, Aku pihak ketiga dari dua orang yang berserikat selagi masing-masing dari keduanya tidak mengkhianati yang lain. Jika salah satu dari keduanya mengkhianati yang lain, Aku keluar dari keduanya. (HR Abu Daud)

Nilai kejujuran dan keadilan dalam kerjasama ini akan membawa rahmat ketenteraman dan kesejahteraan. Keuntungan

${ }^{21}$ Umar Farouk, Kelembagaan dan Operasional Perbankan Syariah Di Indonesia,www.wiki@.com.id. 11 oktober 2017.

${ }^{22}$ Departemen Agama, Mushaf Al-Qur an dan Terjemahnya (Jakarta: Pustaka Al-Kausar, 2009. 
yang dihasilkannyapun akan membawa berkah. Begitu pula sebaliknya, penghianatan kerjasama bisnis hanya akan menjauhkan seseorang dari rahmat dan berkah Allah SWT. Oleh karena itu prinsip kehati-hatian dan kewaspadaan tetap diperlukan sebelum melakukan kerjasama (syirkah) sekalipun dengan orang yang sangat kita kenal sesama muslim.

\section{Bentuk-bentuk Kerjasama Musyarakah}

Menurut Zuhaily dalam Ismail Nawawi menyatakan musyarakah dibagi menjadi dua jenis, yakni musyarakah kepemilikan (Syirkah al-amlak) dan musyarakah akad (syirkah al-'aqd). Syirkah kepemilikan tercipta karena warisan, wasiat dan kondisi lain yang mengakibatkan pemilikan satu aset oleh dua orang atau lebih. Dalam musyarakah ini, kepemilikan dua orang atau lebih terbagi dalam dua aset nyata dari keuntungan yang dihasilkan aset tersebut.

Musyarakah akad tercipta karena kesepakatan dua orang atau lebih yang menyetujui bahwa tiap-tiap orang dari mereka memberikan kontribusi dari modal musyarakah, mereka pun sepakat berbagi keuntungan dan kerugian. Musyarakah akad terbagi menjadi syirkah al-mufadhah, al-inan, al-wujuh dan syirkah al-amal. ${ }^{23}$

\section{a. Syirkah Mufawadhah}

Dalam Syirkah ini bahwa salah satu dari orang yang berserikat itu mendelegasikan semua pengelolaan uang dan aktifitas jual beli, menjual, membeli, mengadakan peminjaman, penugaskan seseorang dan lainnya kepada teman sekutunya, kemudian keuntungannya dibagi di antara mereka berdua sesuai kesepakatan keduanya dan kerugiannyapun dibagi sesuai dengan jumlah uang keduanya. ${ }^{24}$

b. Syirkah Inan

Syirkah inan adalah kerjasama, adalah kontrak setiap pihak memberikan suatu porsi dari keseluruhan dana dan berpartisipasi dalam kerja. Kedua pihak berbagi dalam keuntungan dan kerugian sebagaimana yang disepakati antara

${ }^{23}$ Nawawi, Fikih Muamalah Klasik, h. 153.

${ }^{24}$ Kyai Susilo Purnomo, Pengasuh Pondok Pesantren Sunan Kali Jogo, Klaten (2007). 
mereka. Namun porsi masing-masing pihak, baik dalam dana maupun kerja atau bagi hasil, berbeda sesuai dengan kesepakatan mereka,(semua ulama membolehkan jenis musyarakah ini). ${ }^{25}$ Masing-masing pihak yang terlibat dalam perseroan modal punya wewenang yang sama dalam membatalkan transaksi, membelanjakan hatta persis seperti kedua ujung tali kekang. ${ }^{26}$

Syirkah Inan (serikat harta), akad dua orang atau lebih untuk berserikat harta yang ditentukan oleh keduanya dengan maksud mendapat keuntungan (tambahan) dan keuntungan itu untuk mereka yang berserikat itu. Mengenai syirkah Inan ini para ulama telah bersepakat mengenai sahnya hanya ada sedikit perbedaan paham tentang syarat dan cara-caranya. ${ }^{27}$

c. Syirkah al-wujuh

Kontrak antara dua orang atau lebih yang tidak memiliki modal sama sekali, tetapi memiliki keahlian dalam bisnis. Mereka membeli barang secara kredit dari sebuah perusahaan dan menjual barang tersebut secara tunai. Mereka berbagi keuntungan dan kerugian berdasarkan jaminan kepada penyuplai yang disediakan oleh tiap mitra. Jenis musyakah ini tidak memerlukan modal karena pembelian secara kredit berdasarkan jaminan tersebut. Maka kontrak ini pun lazim disebut musyarakah piutang (para ulama memperselisihkan perserikatan seperti ini) baik modal maupun kerja yang diakadkan tidak jelas. ${ }^{28}$ Para ulama memperselisihkan perserikatan seperti ini, alasannya objek dalam perserikatan adalah modal dan kerja, sedangkan dalam syirkah al-wujuh, baik modal maupun kerja yang diakadkan tidak jelas.

d. Syirkah Abdan

Syirkah Abdan adalah persekutuan antara dua orang atau lebih yang sepakat menggabungkan tenaganya untuk menyelesaikan suatu pekerjaan. Kerjasama ini misalnya dalam

${ }^{25}$ Nawawi, Fikih Muamalah Klasik, h. 153.

26 Syarifudin, R.A, Bisnis Halal Bisnis Haram (Jombang: Lintas Media, 2007), h. 115.

27 Sulaiman Rasyid, Fiqh Islam (Bandung: Sinar Baru Algensindo, 2012), h. 295.

${ }^{28}$ Nawawi, Fikih Muamalah Klasik, h. 154.

Volume 29 Nomor 2 Juli-Desember 2018 
pembuatan rumah. Syirkah ini sering pula disebut syirkah amal. Mereka mendapatkan keuntungan sesuai dengan keterampilan dan keahlian masing-masing yang sesuai dengan kesepakatan mereka. ${ }^{29}$ Mereka merujuk kepada bukti-bukti termasuk persetujuan terbuka oleh Nabi, lagi pula hal ini didasarkan kepada perwakilan (wakalah) yang juga dibolehkan. Dalam musyarakah jenis ini telah sangat lama dipraktekkan.

\section{Produk Hukum tentang Musyarakah di Indonesia.}

Dalam konteks hukum di Indonesia telah ditemukan beberapa produk hukum yang berkaitan dengan masalah musyarakah, baik dalam bentuk pearaturan perundang-undangan maupun dalam bentuk fatwa Dewan Syariah Nasional Majelis Ulama Indonesia (DSN MUI), undang-undang pertama yang menyebutkan tentang istilah musyarakah adalah UU Nomor 10 tahun 1998, musyarakah disebut sebagai salah satu bentuk pembiayaan bagi hasil. ${ }^{30}$

Undang-undang lain yang menyebutkan musyarakah adalah UU Nomor 19 Tahun 2008 tentang surat berharga syariah negara, pada pasal 1 ayat 7 disebutkan bahwa musyarakah adalah akad kerja sama antara dua atau lebih untuk menggabungkan modal, baik dalam bentuk uang maupun dalam bentuk lainnya, dengan tujuan memperoleh keuntungan yang akan dibagikan sesuai dengan nisbah yang telah disepakati sebelumnya, sedangkan kerugian yang timbul akan ditanggung bersama sesuai dengan jumlah partisipasi modal masing-masing pihak. $^{31}$

Produk hukum lain yang membahas tentang musyarakah adalah Fatwa DSN MUI, yaitu fatwa Nomor 8/DSNMUI/V/2000 tanggal 13 April 2000, tentang pembiayaan musyarakah. Dalam fatwa disebutkan ketentuan umum bahwa :

a. Pernyataan ijab dan Kabul harus dinyatakan oleh para pihak untuk menujukan kehendak mereka dalam mengadakan kontrak (akad) deng memperhatikan : a) Penawaran dan

${ }^{29}$ Syarifudin, Bisnis Halal Bisnis Haram, h. 114.

${ }^{30}$ UU Nomor 10 Tahun 1998 tentang perubahan UU Nomor 7 Tahun 1992 tentang Perbankan.

${ }^{31}$ UU Nomor 19 Tahun 2008 tentang Surat Berharga Syariah Negara. 280 
menerimaan harus secara ekplisit menunjukan tujuan kontrak (akad), b) penerimaan dan penawaran dilakukan pada saat kontrak, c) Akad dituangkan secara tertulis melalui korespondensi atau menggunakan komunikasi modern.

b. Pihak berkontrak harus cakap hukum dan memperhatikan hal-hal berikut : a) Kompeten dalam memberikan atau diberikan kekuasaan perwakilan, b) Setiap mitra harus menyediakan dana dan pekerjaan serta melaksanakan kerja sebagai wakil, c) Setiap mitra memiliki hak untuk mengatur aset musyarakah dalam proses bisnis normal, d) Setiap mitra memberikan wewenang kepada mitra yang lain untuk mengelola aset dan masing-masing dianggap telah diberi wewenang untuk melakukan aktivitas musyarakah dengan memperhatikan kepentingan mitranya, tanpa melakukan kelalaian dan kesalahan yang disengaja, e) Seorang mitra tidak diizinkan untuk mencairkan atau menginvestasikan dana untuk kepentingan sendiri.

c. Objek akad (modal kerja, keuntungan dan kerugian) :

1) Modal.

a) Modal yang diberikan harus uang tunai, emas, perak, atau yang nilainya sama. Modal dapat berupa aset perdagangan seperti barang-barang, properti, dan sebagainya. Jika modal berbentuk aset harus terlebih dahulu dinilai dengan tunai dan disepakati oleh para mitra.

b) Para pihak tidak boleh meminjam, meminjamkan, menyumbangkan, atau menghadiahkan modal musyarakah kepada pihak lain kecuali atas dasar kesepakatan.

c) Pada prinsipnya dalam pembiayaan musyarakah tidak jaminan, namun untuk menghindari penyimpangan, Lembaga Keuangan Syariah (LKS) dapat meminta jaminan.

2) Kerja.

a) Partisipasi para mitra dalam pekerjaan merupakan dasar pelaksanaan musyarakah, namun kesamaan porsi kerja bukan merupakan syarat, seorang mitra boleh melaksanakan kerja lebih banyak dari pada 
yang lain, dan dalam hal ini boleh menuntut bagian keuntungan tambahan bagi dirinya.

b) Setiap mitra melaksanakan kerja dalam musyarakah atas nama pribadi dan mitra dari wakilnya, kedudukan masing-masing dalam organisasi kerja harus dijelaskan dalam kontrak.

3) Keuntungan.

a) Keuntungan harus dikuantifikasi secara jelas untuk menghindarkan perbedaan dan sengketa pada waktu alokasi keuntungan atau penghentian musyarakah.

b) Setiap keuntungan mitra harus dibagi secara proporsional atas dasar seluruh keuntungan dan tidak ada jumlah yang ditentukan di awal yang diterapkan bagi seorang mitra.

c) Sistem pembagian keuntungan harus tertuang dengan jelas dalam akad.

4) Kerugian. Kerugian harus ditanggung para mitra secara proporsional menurut modal masing-masing.

5) Biaya operasional dan persengketaan.

a) Biaya operasional dan dibebankan pada modal bersama.

b) Jika salah satu pihak tidak menunaikan kewajiban atau di antara pihak terjadi perselisihan, maka maka perselisihannya dilakukan secara musyawarah, bila tidak tercapai kesepekatan diselesaikan melalui Badan Arbitrasi Syariah. ${ }^{32}$

\section{Implementasi Musyarakah di Perbankan Syariah dan Baitul Mal Wat Tamwil (BMT)}

Seperti kita ketahui bersama penyaluran dana dalam bank konvensional, kita kenal dengan istilah kredit atau pinjaman, sedangkan dalam bank syariah untuk penyaluran dana kita kenal dengan pembiayaan. Jika dalam bank konvensional keuntungan bank diperoleh dari bunga yang dibebankan, maka dalam bank

32 Ikatan Bankir Indonesia, Memahami Bisnis Bank Syraih (Jakarta: Gramedia Pustaka Utama, 2014), h. 42. 
syariah tidak ada istilah bunga, akan tetapi bank syariah menetapkan sistem bagi hasil.

Di dalam praktek perbankan syariah, musyarakah merukan perjanjian kesepakatan bersama antara para pemilik modal untuk menyertakan modal sahamnya pada suatu proyek, karena umumnya pengoperasian uang sebagai modalnya, maka dapat dipastikan bahwa musyarakah yang digunakan adalah syirkah al-mal yakni syirkah al-inan dan syirkah almufawadhah, namun dalam prinsip operasional perbankan syariah tidak menentukan mesti sama dalam permodalan, bisa dipastikan pula bahwa musyarakah yang dipergunakan perbankan syariah adalah syirkah al-inan.

Menurut Sayyid Sabiq dalam Yadi Janwari menjelaskan bahwa syirkah al- inan merupakan adalah berserikatnya dua orang dalam harta dan keduanya melakukan perniagaan dalam harta tersebut dengan keuntungan dibagi di antara keduanya. Di dalam musyarakah ini tidak disyaratkan sama dalam jumlah modal, wewenang dan keuntungan. ${ }^{33}$

Ada beberapa ketentuan yang harus diperhatikan dalam mengimplementasikan musyarakah dalam perbankan syariah, seperti hal di bawah ini :

a. Pembayaran suatu proyek investasi yang telah disetujui dilakukan bersama-sama dengan mitra usaha yang lain sesuai dengan bagian masing-masing yang telah disepakati.

b. Semua pihak termasuk bank syariah, berhak ikut serta dalam manajemen proyek tersebut.

c. Semua pihak secara bersama-sama menentukan posis keuntungan yang akan diperoleh, pembagian keuntungan ini tidak sebanding dengan pernyataan modal masing-masing.

d. Bila proyek ternyata rugi maka semua pihak ikut menanggung kerugian sebanding dengan pernyataan modal. ${ }^{34}$

Cara penyaluran operasional akad musyarakah di perbankan syariah terjadi pada dana, yang produknya biasa

33 Yadi Janwari, Lembaga Keuangan Syariah (Bandung: Remaja Rosdaskarya, 2015), h. 80.

34 Abdul Azis Dahlan dkk, Ensiklopedi Hukum Islam (Jakarta: Ichtiar Baru Van Hoeve, 1997), h. 195.

Volume 29 Nomor 2 Juli-Desember 2018 
disebut dengan pembiayaan musyarakah, merupakan penyertaan modal yang diberikan bank syariah terhadap nasabah yang telah memiliki sebagian modal, Di dalam implementasinya mekanisme operasional akad musyarakah diawali dengan pengajukan pembiayaan oleh nasabah yang telah memiliki sebagian modal tetapi tidak cukup untuk menjalankan usahanya, kemudian bank merealisasi pengajuan nasabah tersebut dengan investasi sesuai dengan jumlah modal yang dibutuhkan nasabah. Investasi modal yang diberikan bank syariah itu diperhitungkan secara proporsional dengan modal yang dimiliki nasabah, selanjutnya nasabah menjalankan usaha dengan modal gabungan antara modal yang dimiliki dengan modal yang diberikan bank syariah.

Dapat juga diaplikasikan bahwa pembiayaan proyek dalam praktik musyarakah di perbankan syariah, nasabah yang dibiayai dengan bank sama-sama menyediakan dana untuk melaksanakan proyek tersebut, keuntungan dari proyek dibagi sesuai kesepakatan dengan bank setelah terlebih dahulu mengembalikan dana yang dipakai nasabah. Atau juga musyarakah dapat pula dilakukan untuk kegiatan investasi seperti pada lembaga keuangan model ventur.

Untuk lebih memahami musyarakah, dapat kita lihat contoh kasus untuk prinsip musyarakah adalah sebagai berikut : Tn. Rudi hendak melakukan suatu usaha tetapi kekurang modal. Modal yang diperlukan sebesar Rp. 100.000.000. sedangkan modal yang dimiliknya hanya sebesar Rp. 50.000.000. Ini berarti Tn. Rudi kekurangan dan sebesar Rp. 50.000.000. Untuk menutupi kekurangan dana tersebut Tn. Rudi meminta bantu bank syariah, dikabulkan dan disetujui. Dengan demikian modal untuk usaha atau proyek sebesar Rp.50.000.000. dipenuhi oleh Tn. Rudi $50 \%$ dan bank syariah $50 \%$, jika pada akhir proyek tersebut mendapatkan keuntungan sebesar Rp. 30.000.000. maka pembagian hasil keuntungan adalah $50: 50$, artinya 50\% untuk bank syariah Rp. 15.000.000. Sedangkan untuk Tn. Rudi juga 50\% yaitu sebesar Rp. 15.000.000. Dengan catatan Tn. Rudi pada akhir proyek selesai tetap mengembalikan uang bank syariah sebesar Rp. 50.000.000 ditambah Rp. 15.000.000. untuk keuntungan bank syariah dari bagi hasik proyek. 


\section{Penutup}

Dari paparan di atas dapat disimpulkan bahwa sebelum mengadakan sebuah akad, perjanjian perserikatan, kerja sama korporasi pada pembiayaan permodalan syariah terlebih dahulu harus mengetahui, strategi yang dibuat oleh perusahaan yang menjadi rekanan kerja sama, sebab sebuah perusahaan dalam menjalankan roda bisnisnya harus memiliki strategi, yang dilakukan oleh sebuah perusahaan agar bisa tercapai sebuah tujuan perusahaan dengan baik, karena apabila sebuah perusahaan tidak memiliki strategi maka akan berakibat di setiap unit organisasinya akan kehilangan arah dan tujuan, bahkan sangat sulit bagi sebuah perusahaan atau lembaga bisnis kalau ingin bekerja sama dengan perusahaan lain

Salah satu bagian dari sebuah kerja sama antar perusahaan adalah sebuah jaringan usaha sebagai alternatif pilihan, di samping banyak lagi usaha-usaha yang lain. Ada beberapa organisasi jaringan bisnis terkemuka yang menciptakan model aktivitas jaringan yang jika diikuti akan memungkinkan seorang pebisnis untuk membangun kerja sama bisnis baru dan menghasilkan peluang bisnis pada saat yang sama. Sebuah layanan jaringan profesional merupakan implementasi teknologi informasi untuk mendukung jejaring bisnis. Banyak pengusaha berpendapat jaringan bisnis adalah metode yang lebih efektif dengan biaya rendah untuk menghasilkan bisnis baru dari pada iklan.

Menurut ekonomi perusahaan, kerja sama, dikenal dengan modal venture atau joint venture, di mana suatu perusahaan melakukan penggabungan antara dua pihak atau lebih yang mengumpulkan modal untuk mendirikan badan usaha dengan perjanjian tertentu. Pelaksanaan yang dilakukan suatu perusahaan atau lembaga bisnis yang melakukan pembiayaan dalam bentuk penyertaan modal ke dalam suatu perusahaan yang menerima bantuan pembiayaan dengan cara melakukan penyertaan ikut secara langsung ke dalam perusahaan yang dibiayai. Kegiatan yang dilakukan antara lain, bersifat jangka panjang, keuntungan yang dipilih bersifat capital gain, deviden atau tergantung penyertaan modal di bidang jenis yang 
dikerjasamakan, berbentuk usaha baru atau pengembang suatu usaha baru.

Dalam bermuamalah sangat tegas Allah SWT, dengan firmannya, tolong-menolonglah kalian semua dalam mengerjakan kebajikan dan takwa, dan jangan tolong menolong dalam berbuat dosa dan pelanggaran, dan bertakwalah kamu kepada Allah sesungguhnya Allah sangat berat siksaan-Nya.(Qs, al-Maidah:5). Ayat ini menjadi prinsip manusia sebagai makhluk sosial yang memperbolehkan kerja sama, baik secara perusahaan maupun individu. Dalam hal tolong-menolong mengerjakan kebaikan, dan kompetisi untuk mengejar ketakwaan. Sebaliknya dilarang bekerja sama dalam untuk mencelakakan orang lain, melakukan penipuan kepada orang lain, berbuat dosa, batil dan zalim.

Akad musyarakah sebagai landasan dalam melaksanakan sebuah kerja sama, akad musyarakah tercipta karena kesepakatan dua orang atau lebih yang menyetujui bahwa tiaptiap orang dari mereka memberikan kontribusi dari modal musyarakah, mereka pun sepakat berbagi keuntungan dan kerugian. Akad musyarakah terbagi menjadi syirkah almufadhah, al-inan, al-wujuh dan syirkah al-amal

\section{DAFTAR PUSTAKA}

Alma, Buchari. Pengantar Bisnis. Bandung: Afabeta, 2006.

Anoraga, Panji. Manajemen Bisnis. Jakarta: Asdi Mahasatya, 2004 
Antonio, Muhammad Syafii. Bank Syariah dari Teori ke Praktek. Jakarta: Gema Insan, 2001.

Dahlan, Abdul Azis dkk. Ensiklopedi Hukum Islam. Jakarta: Ichtiar Baru Van Hoeve, 1997.

Departemen Agama. Mushaf Al-Qur an dan Terjemahnya. Jakarta: Pustaka Al-Kausar, 2009.

Farouk, Umar. Kelembagaan dan Operasional Perbankan Syariah di Indonesia dalam www.wiki@.com.id. Diakses 11 Oktober 2017.

Hasan, Ali. Manajemen Bisnis Syariah. Yogyakarta: Pustaka Pelajar, 2009.

Hitt, Michael A. dkk. Manajemen Strategis. Jakarta: Salemba Empat, 2001.

http://solusimlm.wordpress.com/2017/19./25/kenapa-bisnispemasaran-jaringan-lebih-unggul/

http://blog.mokapos.com/2017/09/09/20.00.-keuntungan-dalammembangun-jaringan-dan-relasi-dalam-bisnis/

Ikatan Bankir Indonesia. Memahami Bisnis Bank Syariah. Jakarta: Gramedia Pustaka, 2014.

Janwari, Yadi. Lembaga Keuangan Syariah. Bandung: Remaja Rosdakarya, 2015.

Nawawi, Ismail. Fikih Muamalah Klasik dan Kontemporer. Bogor: Ghalia Indonesia, 2012.

Priyono. Pengantar Manajemen. Sidoarjo: Zifatama Publiher, 2014.

Rasjid, Sulaiman. Fiqih Islam. Bandung: Sinar Baru Algensindo, 2012.

Syarifudin R. A. Bisnis Halal Bisnis Haram Jombang: Lintas Media, 2007.

Swastha, Basu dan Irawan. Manajemen Pemasaran Modern. Yogyakarta: Liberty, 2005. 
Umam, Khaerul. Pasar Modal Syariah Bandung: Pustaka Setia, 2013.

Undang-undang Nomor 10 Tahun 1998 tentang Perubahan UU Nomor 7 Tahun 1992 tentang Perbankan.

Undang-undang Nomor 19 Tahun 2008 tentang Surat Berharga Syariah Negara.

Veithzal, Rivai dkk. Islamic Business and Economic Ethics. Jakarta: Bumi Aksara, 2012. 